\title{
The rate of lectures attitude towards academic counseling and its related factors at Kurdistan University of Medical Sciences in 2016
}

\author{
Fariba Tairi $^{1}$, Shaaban Sepehr ${ }^{2}$, Fayegh Yousefi ${ }^{3}$, Yadollah Zarezadeh ${ }^{4}$ \\ 1-M.Sc, Vice Chancellor for Student and Cultural Affairs, Kurdistan University of Medical Sciences, Sanandaj, \\ Iran (Corresponding Author). ORCID: 0000-0002-0203-8219Ｅ-mail: Faribafaran94@gmail.com \\ 2- GP, Vice Chancellor for Student and Cultural Affairs, Kurdistan University of Medical Sciences, Sanandaj, \\ Iran. \\ 3- Associate Professor, Department of Clinical Psychology, Faculty of Medicine, Kurdistan University of \\ Medical Sciences, Sanandaj, Iran. ORCID: 0000-0001-5503-3326 \\ 4- Associate Professor, Social Determinants of Health Research Center, Research Institute for Health \\ Development, Kurdistan University of Medical Sciences Sanandaj, Iran. ORCID: 0000-0001-9311-0038
}

Received: 19/12/2018

Accepted: 11/03/2019

\begin{abstract}
Introduction: Student counseling is one of the most important preventive strategies in University. The consultant's professor is a member of the faculty who has accepted the consulting and consulting services with an invitation, and helps the student to match his interests and abilities with an educational program and an interim evaluation of his progress at the university.

Aim: The purpose of this study was to determine the attitude and knowledge of counselors in educational counseling its related factors were in Kurdistan University of Medical Sciences.

Method: In this descriptive-analytical study, a total of 110 faculty members from Kurdistan University of Medical Sciences in all disciplines and colleges were selected through census sampling. The data collection tool was a questionnaire including demographic information of faculty members, a questionnaire of 18 questionnaires and a questionnaire on knowledge of the duties of counselor professor 20 questions were completed. After collecting information, data were analyzed using SPSS 22 software, Pearson correlation, T test and ANOVA statistical tests.

Results: The highest frequency of positive attitude toward educational counseling in the subjects was moderate with a relative frequency of $74.5 \%$. The highest frequency of awareness of the duties of counselor in the subjects was $64.22 \%$. There was a significant relationship between the level of knowledge about the duties of the consultant's counselor and the attitude toward educational counseling in the subjects. $(\mathrm{P}<001)$

Conclusion: Having a high attitude toward academic counseling and knowing the duties of the consultant's professor on average in the subjects can be a good and suitable field for raising awareness and participating in the provision of services to the students.
\end{abstract}

Keywords: Attitude and consciousness, Educational counseling, Consultant professors

How to cite this article : Tairi F, Sepehr Sh, Yousefi F, Zarezadeh Y. The rate of lectures attitude towards academic counseling and its related factors at Kurdistan University of Medical Sciences in 2016. Shenakht Journal of Psychology and Psychiatry. 2019; 6 (2): 161-170 . URL :http://shenakht.muk.ac.ir/article-1-697-fa.pdf

Copyright $\odot 2018$ the Author (s). Published by Kurdistan University of Medical Sciences. This is an open access article distributed under the terms of the Creative Commons Attribution-Non Commercial License 4.0 (CCBY-NC), where it is permissible to download, share, remix, transform, and buildup the work provided it is properly cited. The work cannot be used commercially without permission from the journal. 


\title{
بررسى ميزان نكرش وآكاهى اساتيد مشاور نسبت به مشاوره تحصيلى و عوامل مربوط آن در

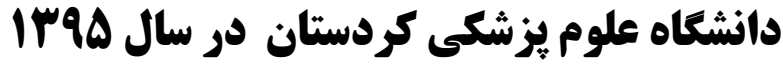

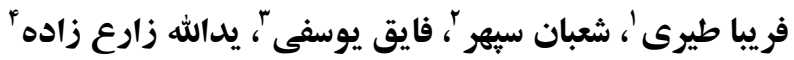
ا.كارشناسى ارشد روانشناسى بالينى، كروه آموزشى روانشناسى بالينى، دانشكاه علوم يزشكى كردستان، سندج، ايران (مولف مسئول). ايميل: faribafaran94@gmail.com

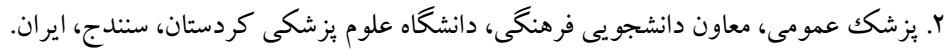

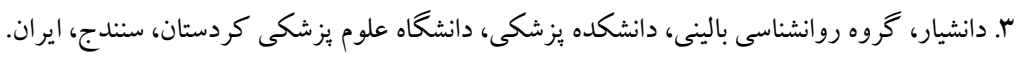

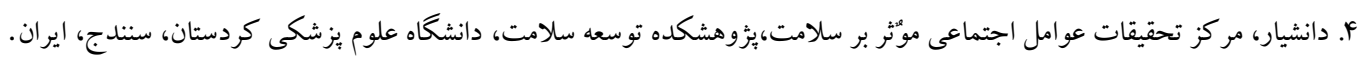

مقدمه: مشاوره و راهنمايى دانشجويان يكى از مهم ترين راهبردهاى ييشگيرى در دانشگاه به حساب مى آيد. استاد مشاور،

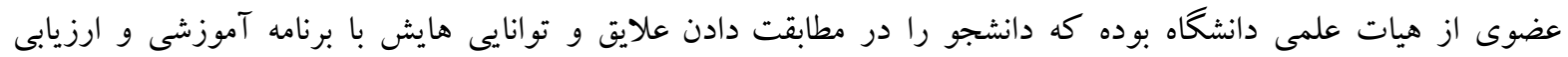
متناوب ازييشرفتش در دانشكاه كمك مئ مى كند. هدف: هدف مطالعه حاضر تعيين ميزان نخرش وآكاهى اساتيد مشاور نسبت به مشاوره تحصيلى وعوامل مربوط آن دردانشگاه علوم يزشكى كردستان بوده است. روش: در اين ئزوهش توصيفى تحليلى •ll نفر از اساتيد مشاوردانشگاه علوم يزشكى كردستان در تمام رشته ها و دانشكده ه با

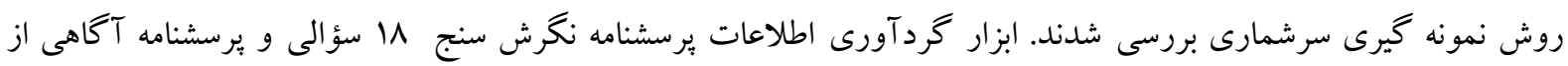

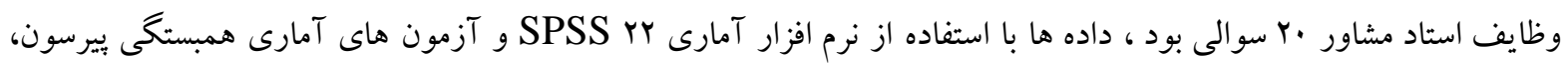
تى تست وآنوا تجزيه و تحليل شد. يافتهها: بيشترين فراوانى ميزان نخرش مثبت نسبت به مشاوره تحصيلى در افراد مورد مطالعه در حد متوسط با فراوانى نسبى

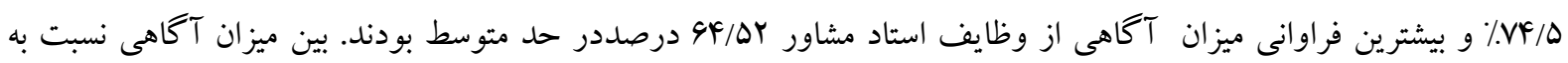

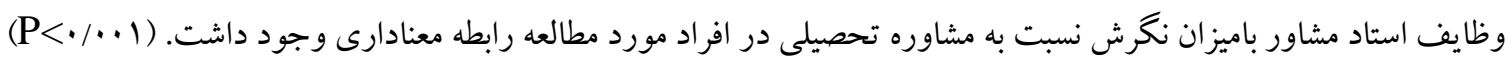
نتيجه كيرى: وجود نكرش بالا نسبت به مشاوره تحصيلى و آكاهى از وظايف استاد مشاور در حد متوسط در افراد مورد مطالعه،

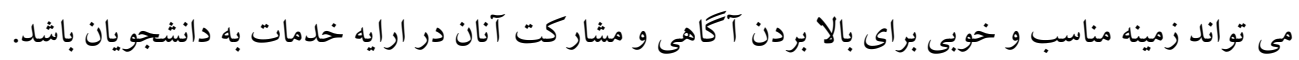
كليدوازه: نخرش و آكاهى، مشاوره تحصيلى، اساتيد مشاور 
قبلى در خانواده، ورود به زندگى دانشجويى و نياز به

مقدمه

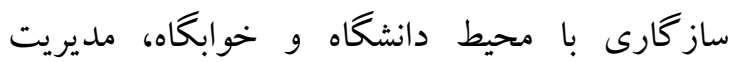
مسايل معيشتى، تحصيلى و عاطفى اشاره كرد. بنابراين

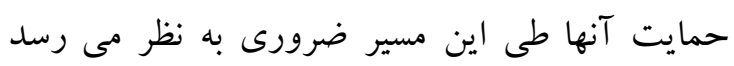

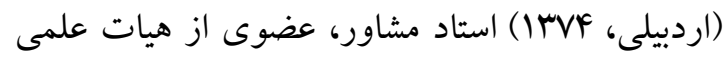
دانشگاه بوده كه خدمات مشاوره وراهنمايى را با يكى دعوت بذيرفته است و دانشجو را در مطابقت دادن علايق و توانايى هايش با برنامه آموزشى و ارزيابى

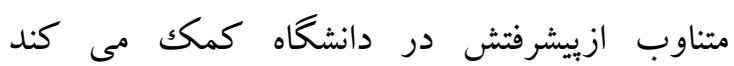
(شمس و همكاران، هم/1). خود آكاهى، مهارت هاى برقرارى ارتباط، تسهيلات معتبر، اعتماد به نفس، در دسترس بودن، مسئوليت يذيرى، توانايى همدلى و

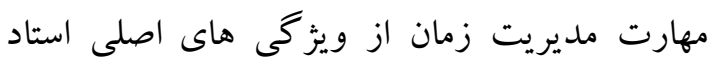

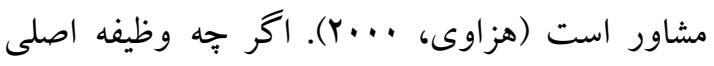
مدرس تدريس و برورش قواى ذهنى دانشجو است، ولى جنان جه مشاور به اصول وفنون راهنمايى و

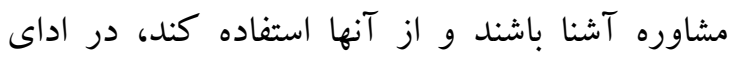
وظيفه اش موفقتر خواهد بود و اعتماد به نفس

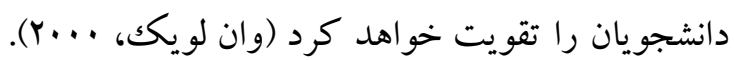
نتايج تحقيقات بيانكر آن هستند كه مشاوره تحصيلى موجب بازدهى و كارآيى بيشتر نظام آموزشى شده و

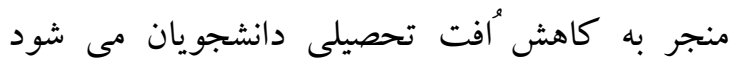

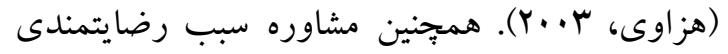
دانشجويان از تحصيل در دانشگاه شده و مشوقى براى دستيابى به اهداف متعالى آموزشى براى آنان بوده و منجر به افزايش سخت كوشى آنان مىشود (لين،

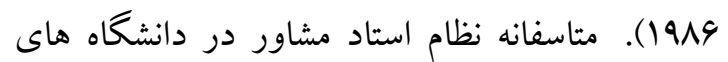
ايران، به دليل گرفتارى آموزشى، فقدان تخصص لازم، بى علاقكى به رفع مشكلات دانشجويان، تمام وقت نبودن اساتيد و عدم اطلاع كافى دانشجويان ازحيطه وظايف استاد مشاور نتوانسته است نتايج درخشانى به بار آورد. در بررسى تحقيقات قبلى با دانشگاهها و محيطهاى دانشجويى كه در بر گيرنده بخش قابل ملاحظه اى از نخبگان و فرهيختگان جوان جامعه هستند، همسو با فضاى درحال كذار موجودة،

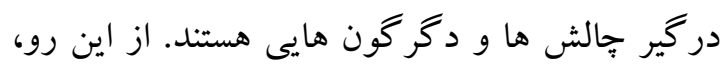
تغذيه و حمايت ذهنى، روانى و اجتماعى دانشجويان و دانشگاهيان و برقرارى ارتباط متقابل و تعامل با آنان امرى ضرورى به نظر مىرسد (اردبيلى،

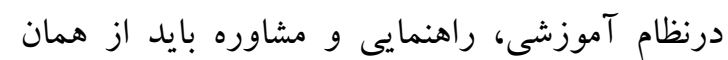
ابتداى ورود به محيط آموزشى آغاز و تا بايان دوران

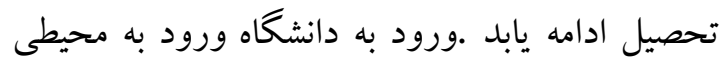
جديد است كه از لحاظ آموزشى تفاوت هاى آشكارى با محيط هاى آموزشى قبلى داشته و و دانشجويان با ورود به آن، با مسايل و معضلاتى جديد روبه رو خواهند شد كه فايق آمدن بر آنها نياز به وجود يكك مشاور در كنار دانشجو را ضرورى جلوه خواهد داد .مشاوره و راهنمايى دانشجويان يكى از مهم ترين راهبردهاى بيشگيرى در دانشگاه به حساب مى آيد .مشاوره تحصيلى، رابطه اى بويا و هدفمند است كه براساس مشاركت استاد و دانشجو و با لـ روشهايى منطبق بر نيازمندى هاى دانشجو انجام

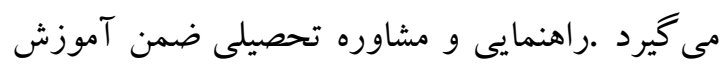

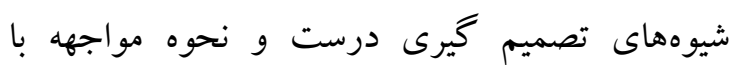

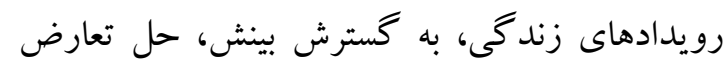

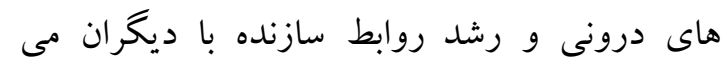
انجامد و درنهايت موجب بازدهى و كار آمدى بيشتر نظام آموزشى و كاهش افت تحصيلى مى شود (شفيع

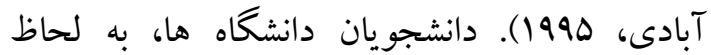
حساسيت دوران رشد و تحول و شرايط بحرانى اين

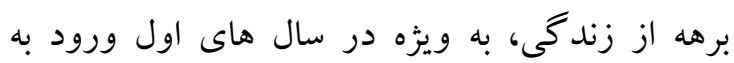

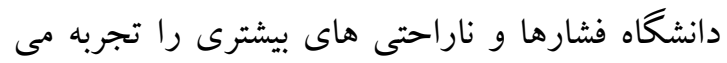

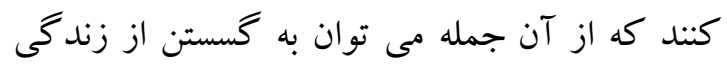


دانشگاه علوم بزشكى كردستان بودند كه به طريق نمونه گيرى سرشمارى، به عنوان نمونه در نظر گرفته

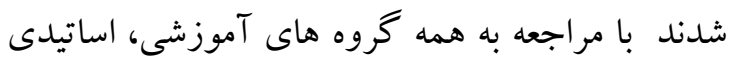
كه مايل به همكارى بودند برسشنامه هاى نخرش سنج

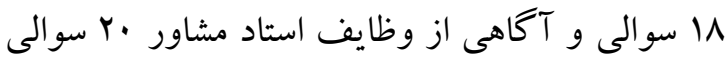
را تكميل نمودند. يس از جمع آورى كليه برسشنامه

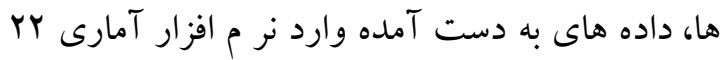
Tآمارى گرديد و اهداف توصيفى با استفاده

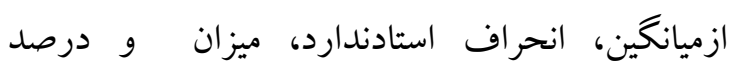
محاسبه شد. براى آناليز رابطه ميزان نخرش نسبت به مشاوره تحصيلى (متغير رتبه اى و وابسته) با مرتبه علمى و دوره هاى كذرانيده آموزشى و (متغير اسمى و وتئي مستقل) و همجنين ميزان آكاهى از وظايف استاد مشاور(متغير وابسته و رتبه اى) و آزمون هاى آمارى

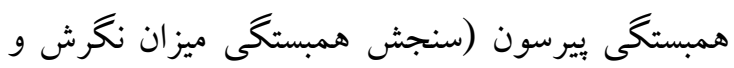
آكاهى نسبت به مشاوره تحصيلى)، استفاده شد. سطح معنى دار در كليه آزمون هاى بثزوهش نيز كمتر از

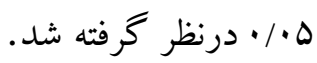

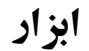

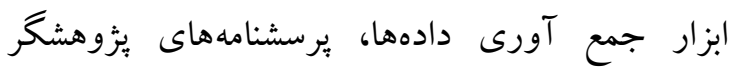

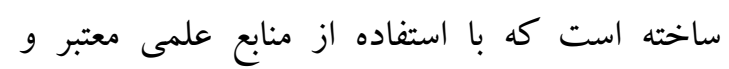
مرتبط تهيه و در سه بخش تنظيم گرديده است. بخش اول، مشخصات فردى و بخش دوم، حاوى 11 سؤال نكر ش سنج بر اساس مقياس ينج درجه اى ليكرت

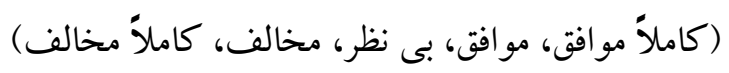
مقياس ينج درجه ايى ليكرت: با توجه به بار

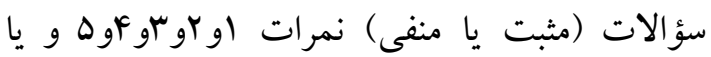
بالعكس براى هر بِاسخ در نظر گرفته شده و حاصل

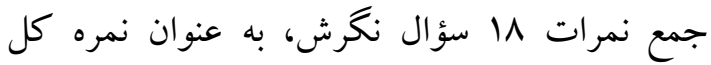

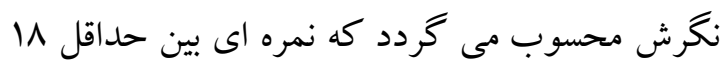

وجودى كه مطالعات زيادى در زمينه نخرش دانشجويان به مشاوره و راهنمايى تحصيلى انجام شده

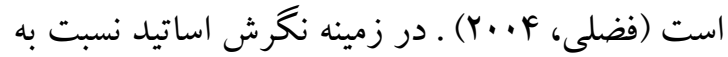
مشاوره و راهنمايى تحصيلى،مطالعات كمى صورت

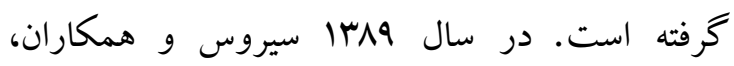
فر آيند استاد راهنماى آموزشى را در دانشكده بزشكى اصفهان از ديدگاه دانشجويان و اساتيد بررسى

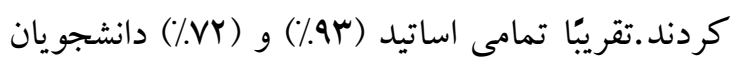
فر آيند استاد راهنما را ضرورى دانستند. اسداللهى وهمكاران در ارتباط با وضعيت موجود و مطلوب مشاوره در دانشگاه جندى شايور اهواز روى اعضاى هيات علمى كزارش نمودند كه اكثر اعضاى هيات علمى به امر مشاوره و راهنمايى دانشجويان علاقه مند هستند ولى از وظايف استاد مشاور در حد متوسط

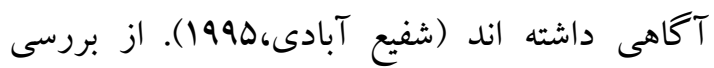
بيشينه مطالعات قبلى اينكونه مى توان استنباط كرد كه

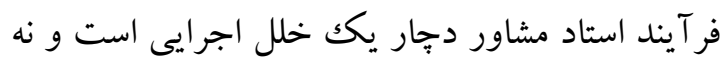
تنها از سوى دانشجويان بلكه از سوى اساتيد مشاور

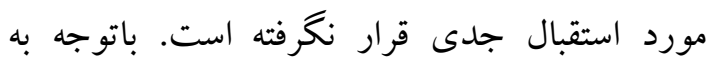

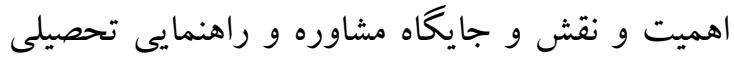
در جهت رفع مشكلات دانشجويان خصوصا افت تحصيلى و به دليل آنكه اطلاعات روشن ومشخص از وضعيت ارائه اين خدمات به دانشجويان در دسترس نيست، هدف مطالعه حاضر تعيين ميزان نخرش

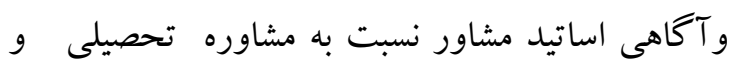
عوامل مربوط آن در دانشگاه علوم يزشكى كردستان

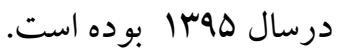

يزوهش حاضر از نوع مطالعات توصيفى-تحليلى بوده كه به صورت مقطعى سال تحصيلى له9 و و9 انجام كرفت. جامعه Tارمى شامل به M نفر از اساتيد مشاور 
حضورى در محل كار در اختيار اعضاى هيأت علمى

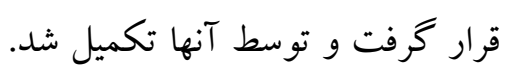

يافته ها يرسشنامهاى تكميل شده كنترل شد و بعلت مخدوش و ناقص بودن باسخ ها بطور قطع تعداد ·ـ 11 برسشنامه

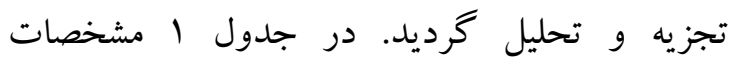
دمو گرافيك اساتيد نشان داده شده است. بيشترين فراوانى مربوط به اساتيد مرد با و/ و/\%٪ بود. نزديك به به

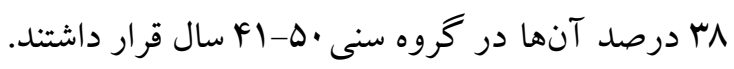

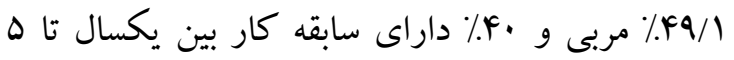

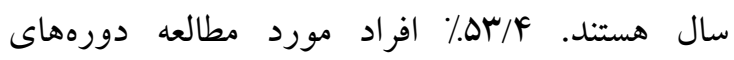
آموزشى مربوطه را كذرانيده بودند.
تا حداكثر ·9 مى باشد. در بخش سوم برسشنامه، وظايف اساتيد مشاور در قالب •r سؤال بر اساس آيينامه وزارتى مطرح كرديده و اساتيد ميزان موافقت خود را با هر يكك از وظايف مطرح شده بر روى يكك مقياس بنج درجه ایى ليكرت (كاملاً موافق،

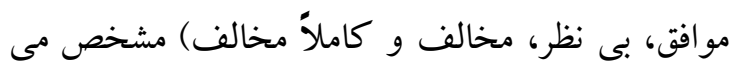

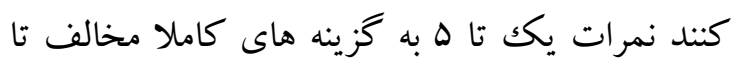
كاملا موافق تعلق ميگيرد و حاصل جمع نمرات r. و نمره ایى بين ·بتا حداكثر ..1 است. روايى و اعتبار

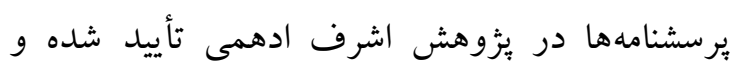
جون سوالات بركرفته از بخشنامه شوراى عالى برنامه

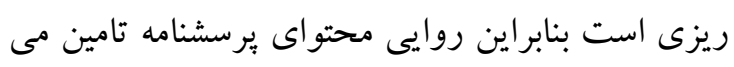

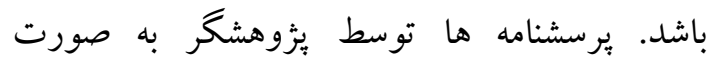

جدول ا توزيع فراوانى متغيرهاى جمعيت شناختى در افر اد مورد مطالعه

\begin{tabular}{|c|c|c|c|c|}
\hline درصد & فراوانى & \multicolumn{2}{|c|}{ متغير هاى جمعيت شناختى } & رديف \\
\hline$\% 1 \cdot 19$ & ir & زير ·r سال & \multirow[t]{4}{*}{ كروه سنى } & \multirow[t]{4}{*}{1} \\
\hline$\%$ & rq & الاتا •F سال & & \\
\hline$\% \mathrm{rV} / \mathrm{A}$ & fr & أF تا •ه سال & & \\
\hline$\% 1 \Delta / \Delta$ & iv & اله به بالا & & \\
\hline$\%$ /.MG/F & f. & زن & \multirow[t]{2}{*}{ جنسيت } & \multirow[t]{2}{*}{$r$} \\
\hline$\% .94 / 9$ & v. & مرد & & \\
\hline$\% F q / 1$ & $\Delta F$ & مربى & \multirow{4}{*}{ وضعيت مرتبه علمى } & \multirow[t]{4}{*}{$r$} \\
\hline$\% F r / V$ & FV & استاديار & & \\
\hline$\% .9 / 4$ & V & 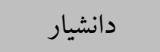 & & \\
\hline$\% 1 / \wedge$ & r & استاد تمام & & \\
\hline$\% \Delta r / F$ & $1 Y 9$ & 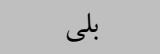 & \multirow{2}{*}{ هذراندن دوره } & \multirow[t]{2}{*}{ r } \\
\hline$\% 49 / 9$ & 11. & 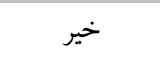 & & \\
\hline$\%$ & FF & اتا ه سال & \multirow[t]{4}{*}{ سابقه كار } & \multirow[t]{4}{*}{$\Delta$} \\
\hline$\%$ \%r/V & rq & 9 تا • اسال & & \\
\hline$\% 19 / 1$ & $r_{1}$ & 11 & & \\
\hline$\% / \mathrm{N} / \mathrm{r}$ & 9 & ا Y سال به بالا & & \\
\hline
\end{tabular}


جنسيت مرد با س/ بو درصد و بيشترين سابقه كار ا تا ه سال با فراوانى .F. مرصد مى باشد.
طبق جدول شماره ا بيشترين فراوانى گروه سنى مربوط به

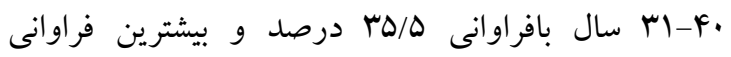

جدول ب توزيع فراوانى ميزان نكرش اساتيد مشاور نسبت به مشاوره تحصيلى در افراد مورد مطالعه

\begin{tabular}{|c|c|c|}
\hline درصد & فراوانى & ميزان نكرش \\
\hline $1 F / 0$ & 19 & r \\
\hline$V F / \Delta$ & $\wedge r$ & متوسط \\
\hline $1 \cdot / 9$ & ir & زياد \\
\hline $1 \ldots$ & 11. & كل \\
\hline
\end{tabular}

طبق جدول Y بيشترين فراوانى ميزان نگرش اساتيد مشاور نسبت به مشاوره تحصيلى در افراد مورد مطالعه در حد متوسط با فراوانى نسبى

\begin{tabular}{|c|c|c|}
\hline درصد & فراوانى & وضعيت آكاهى \\
\hline $1 F / 0$ & 19 & r \\
\hline$s F / D$ & VI & متوسط \\
\hline$r \cdot / 9$ & rr & بالا \\
\hline $1 \ldots$ & 11. & كل \\
\hline
\end{tabular}

طبق جدول ب بيشترين فراوانى ميزان آكاهى از وظايف استاد مشاوردر افراد مورد مطالعه در حد متوسط با فراوانى نسبى . \% مى باشد.

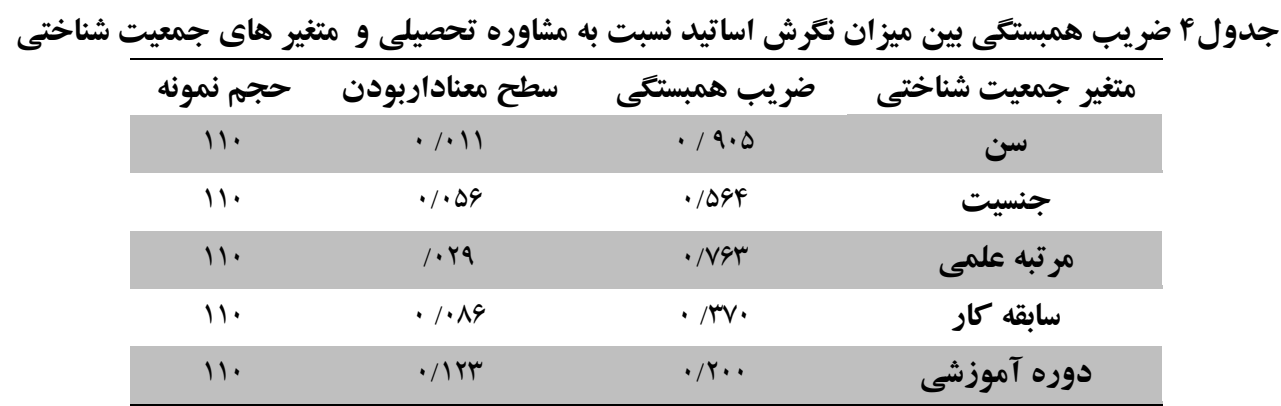

جدول F نشان مىدهد كه ضريب همبستخى بين ميزان نخرش اساتيد نسبت به مشاوره تحصيلى و متغيرهاى جمعيت شناختى رابطه معنادارى بين متغير ها را نشان نمى دهد .

جدوله ضريب همبستكى بين ميزان آكاهى از وظايف استاد مشاور و متغير هاى جمعيت شناختى

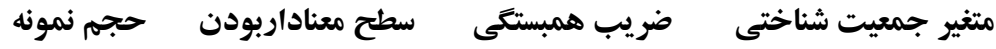

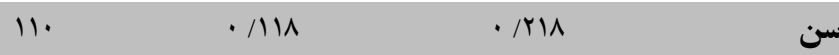




\begin{tabular}{|c|c|c|c|}
\hline 11. &.$/ 119$ &.$/ 1 F q$ & جنسيت \\
\hline 11. & I.YY & $\cdot|\wedge Y|$ & مرتبه علمى \\
\hline 11. & .1 .49 & $\cdot 19.9$ & سابقه كار \\
\hline 11. & $\cdot / \cdot \sqrt{ } 1$ & - /FGY & دوره آموزشى \\
\hline
\end{tabular}

جدول ه نشان مى دهد كه ضريب همبستگى بين ميزان آكاهى از وظايف استاد مشاور و متغير هاى جمعيت شناختى رابطه معنادارى بين متغيرها را نشان نمىدهد.

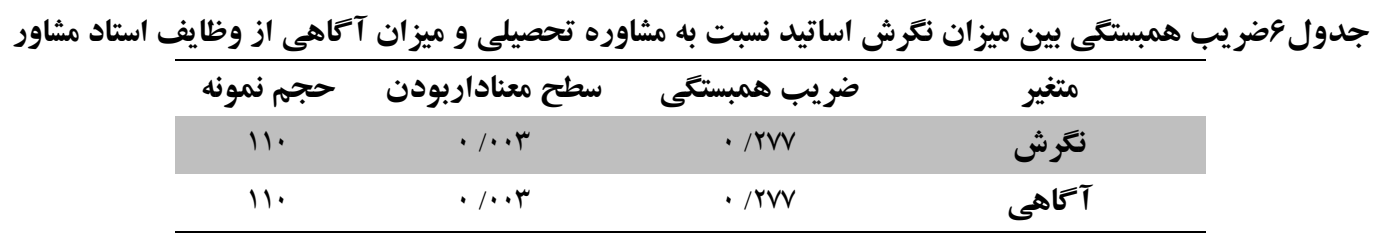

جدول 9 نشان مىدهد كه ضريب همبستخى بين دو متغير ميزان نخرش اساتيد نسبت به مشاوره تحصيلى و ميزان آكاهى

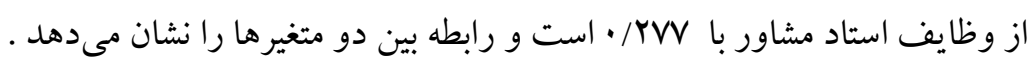

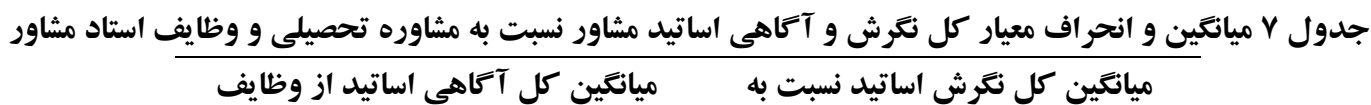

\begin{tabular}{|c|c|c|c|}
\hline \multicolumn{2}{|c|}{ استاد مشاور و انحر اف معيار } & \multicolumn{2}{|c|}{ مشاوره تحصيلى و انحر اف معيار } \\
\hline mean & $\Lambda F / Y \pm \wedge / 1$ & mean & $q \cdot / F \pm \Delta / F r$ \\
\hline كمترين & 4. & كمترين & 01 \\
\hline بيشترين & $1 \ldots$ & بيشترين & $\Lambda \mathrm{V}$ \\
\hline
\end{tabular}

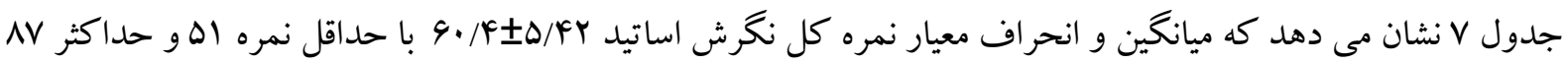

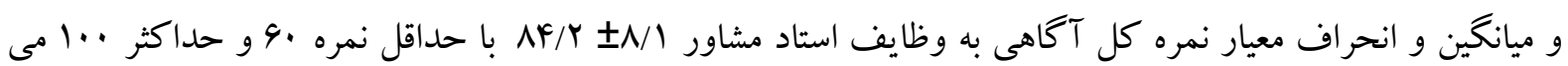
معنادارى آزادى

\begin{tabular}{|c|c|c|c|}
\hline r/.rr & YTD/IGY & 1 & ميز ان آكاهي اساتيد نسبت به مشاوره و وظايف استاد مشاور \\
\hline
\end{tabular}

جدول ^ 1 نشان مى دهد كه بين ميزان نخرش اساتيد بحث نتايج اين مطالعه نشان دادند كه بيشترين فراوانى ميزان

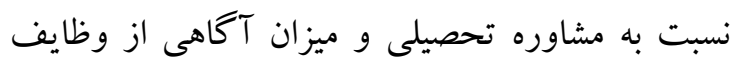

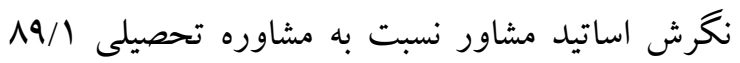

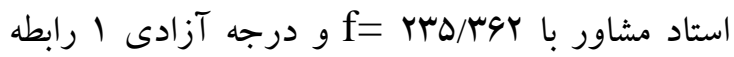
درصد در حد متوسط مى باشد و اين در حالى است كه Pعنادارى وجود دارد. r...• 
تحصيلى مربوط به سوال "براى ساز گارى هرجه بيشتر دانشجويان با محيط دانشگاهى مشاوره امرى لازم است" با ميانخين كل F/ه و وايين ترين نمره نخرش اساتيد مربوط به سوال"در امر مشاوره علاقمندى اساتيد مشاور نقشى ندارد" با ميانخين كل 19 19 بود و ور بايين ترين ميانگين نظرات اساتيد در خصوص آكاهى از وظايف استاد مشاور مربوط به سوال " بيخيرى وضعيت تحصيلى دانشجو در آينده با ميانگين كل ه/ ب مى باشد. از نتايج مطالعه حاضر بنظر مى رسد كه بيش از Nه درصد از اساتيد مشاور نسبت به وظيفه استاد مشاور آكاهى داشتند و بيشترين آكاهى مربوط به دانشكده

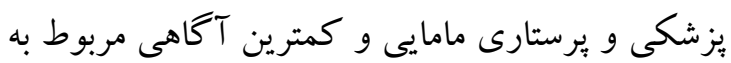
دانشكده دندانبزشكى بود و اينگگ نه استنباط مى شود كرد كه دانشكده يزشكى و برستارى با سابقه بيش از . اطلاعات تئورى، فرصت عملى نمودن و تجربه اندوزى را در خلال اين سالها داشته اند و دانشكده دندانيزشكى كمترين ميزان سابقه كار را در بين دانشكده ها دارد و شايد مسئله استاد مشاور به قوت ساير دانشكده ها در آن جا نيفتاده است و اساتيد آن جون بيشتر بالينى و اهل مطب هستند كمترفرصت مشاوره دادن به دانشجويان را ييدا مى كنند. اين مطالعه با نتايج مطالعه ادهمى در

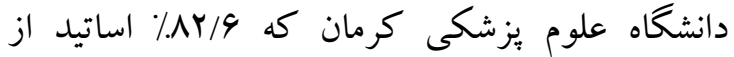
وظايف استاد مشاور آكاهى داشتند و 9^.٪ كاملا موافق با وظايف استاد مشاور بودند هميوشى دارد (ادهمى،

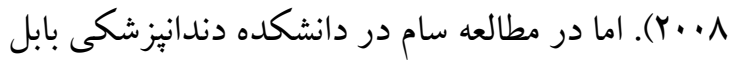
تقريبا نيمى از اساتيد از وظايف استاد مشاور آكًاه

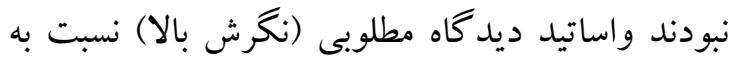

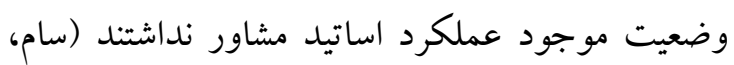

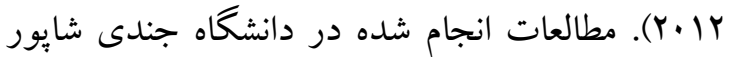
اهواز، علوم يزشكى كرمان و علوم يزشكى اصفهان بيانگر علاقمندى اساتيد به امر مشاوره تحصيلى بوده

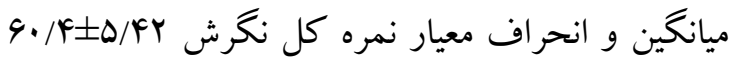
با حداقل نمره اه و حداكثر نمره NV بود و نظرات اساتيد در مورد آكاهى از وظايف استاد مشاور نشان داد

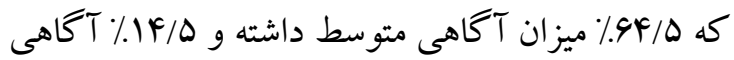
كمى داشتند. ميانخين و انحراف معيار نمره كل نظرات آكاهى نسبت به وظايف استاد مشاور حداقل .9 و حداكثر ..1 بود (جدول شمارهF). مقايسه ميانگين نمرات نخگش با توجه به متغير سن، جنسيت، مرتبه علمى، سابقه كار و دوره آموزشى كذرانيده تفاوت معنادارى نشان نداد (جدول شمارهه). همجنين ميانخين و انحراف معيار نمره آكاهى اساتيدى كه اظهار كرده بودند نسبت به وظايف استاد مشاور آكاهى دارند با متغيرهاى جنسيت، سن، دوره گذرانيده ، سابقه كار و مرتبه علمى رابطه معنادارى نداشتند. اما ضريب همبستگى بين دو متغير ميزان نغرش اساتيد نسبت به مشاوره تحصيلى و ميزان آكاهى اساتيد از وظيفه استاد مشاور نشاننده رابطه معنادارى بين اين دو متغير مى باشد (جدول شماره9). در مطالعات انجام شده مشاوره تحصيلى بر بهبود عملكرد تحصيلى دانشجويان موثر بوده و تاثير آن براى دانشجويانى كه بيشينه تحصيلى بهتر داشتند بيشتر بوده

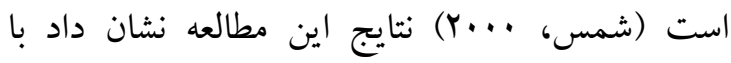
وجودى كه /4/4\% از اساتيد دانشگاه در زمينه مشاوره

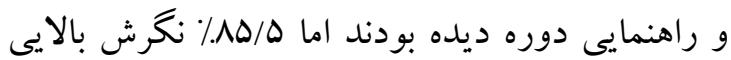
نسبت به مشاوره داشتند و در بين آنان نخرش مربيان بهتر بود و با نتايج مطالعه هزاوه ای در دانشگاه علوم يزشكى همدان و ادهمى در علوم يزشكى كرمان مشابهت دارد (هزاوه اى، .... (Y). شايد بتوان اينطور

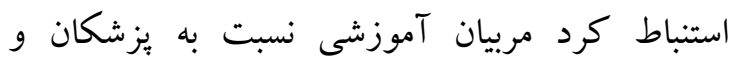
متخصصين كه استاد مشاور دانشجويان هم هستند وقت

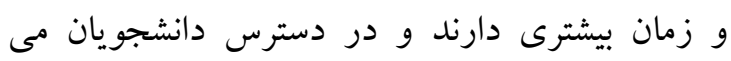

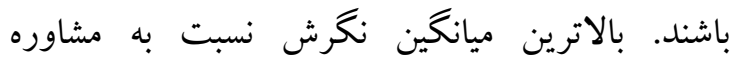


توانمندترى را تحويل اجتماع خواهند داد. با توجه به نتايج اين مطالعه تمام دانشكده ها بويزه دانشكده دندانيزشكى كه قدمت كمترى نسبت به دانشكدهاى ديخر دارد در الويت تقويت اساتيد مشاور و بركزارى كار گاه هاى آموزشى در اين حيطه مىباشند.

\section{سياسگزارى}

اين بزوهش با حمايت مالى معاونت تحقيقات و فن

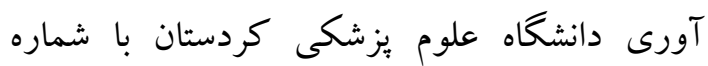
IR.MUK.REC.1395.304 انجام شده است و و از حمايت كنند كان در اجراى اين بثوهش كمال تشكر

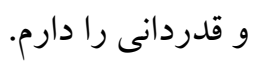

\section{References}

Adhami A, jalili Z, Mohamad alizadeh S, Nohi A, Fatahi Z Faculty Members Attitude towardAcademic Advising and Counseling and their Viewpoints about Counseling Duties. Iranian Joumal of Medical Education 2008 Apr\& sum: 8(1):7-13. (In Persian)

Ardabili U. [Osol va fonoon rahnamaie va moshavareh dar Amoozesh va Parvaresh]. Tehran: Beasat. 1995. (InPersian)

Fazaly A. [Tasir moshavareh dar pishraft tahsily daneshjoian. Pajohesh va Barnamehrizy dar Amozesh Aly 2004; 10(31-32): 61-90. (In Persian)

Hazavehei MM, Emdadi Sh. [The KAP study of faculty members of the Hamadan University of MedicalSciences about academic advising programs in 1998]. Scientific Joumal of Hamadan University ofMedical Sciences and Health Services 2001; 7: 36-43. (In Persian)

Hazavehei MM. [The effect of an educational program based on the PRECEDE Model on the level ofacademic consultants' ability and students' satisfaction]. Joumal of Medical Education 2003; 3(2): 85-9. (In Persian)
است (شفيع آبادى، 1990؛ شمس، 9..ب؟؛ هزاوه ای، (Y... مشاوره تحصيلى بين اساتيد دانشكده دندانيزشكى كم برم بوده است و با مطالعه فعلى ما همخوانى دارد. نتايج

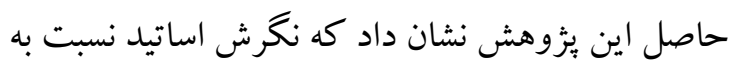

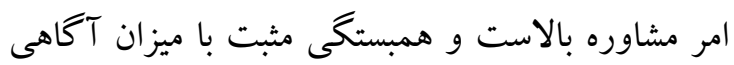
اساتيد از وظايف استاد مشاور دارد بطورى كه بيشترين فراوانى ميزان نخرش استاد مشاور در حد متوسط و بيشترين فراوانى آكاهى از وظايف رادر حد متوسط داشتند. اين نشان مى دهد كه تعداد كمى از اساتيد در

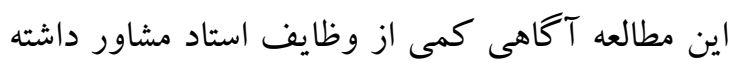
و آن هم تحت تاثير نخرش بايين آنان نسبت به مشاوره تحصيلى مى باشد و مشاوره را امرى كمكى كننده در نر يشرفت تحصيلى دانشجويان نمى دانند.

\section{نتيجه كيرى}

وجود نخرش بالا نسبت به مشاوره تحصيلى و آكاهى از وظايف استاد مشاور در حد متوسط در افراد مورد مطالعه، مى تو اند زمينه مناسب و خوبى براى بالا بردن آكاهى و مشاركت آنان در ارايه خدمات به دانشجويان باشد. مسئولين مىتوانند با اجراى برنامه آموزشى به

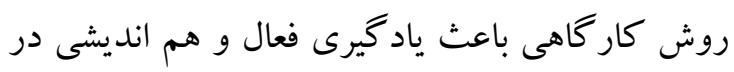
جهت كسب مهارت هاى لازم در اجراى وظايف استاد مشاور شوند. بنابرين بيشنهاد مى گردد در هر ترم تحصيلى كار گاه تقويت عملكرد استاد مشاور توسط

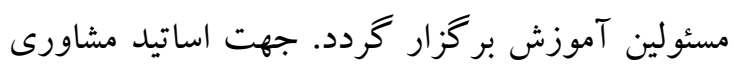
كه بهترين عملكرد را در اجراى آيين نامه استاد

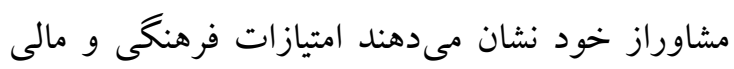
در نظر گرفته شود. بديهى است تقويت عملكرد استاد مشاور در واقع راهكار مثبى در جهت تقويت ارتباط

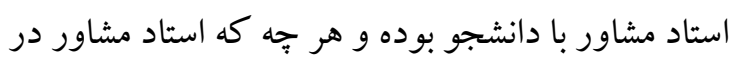
اين زمينه موفق تر باشد دانشجويان سالم تر و و 
Hazavei MM, Fathi Y. [Student's satisfaction from academic guidance and consulation at Hamadan University of Medical Sciences]. Journal of Shahid Sadoughi University of Medical Sciences and Health Services 2000; 2(8): 56. (In Persian)

Jafarpor P 1*, Mohseni moghadam F2, Agha mohammad hasani P3, Sayyadi AR4. Viewpoints of academic advisors of Rafsanjan university of Medical Sciences regarding counseling and their duties as advisor.health social.vol.6.NO.3, 4,2013 (In Persian)

Lynn MR. Determination and quantification of content validity. Nurs Res 1986 Nov-Dec; 35(6): 382-5.

Sam Sh.1 PhD, Seyfi S.* PhD, Ehsani M.2 PhD, Pourghasem M.1 PhD 12- Academic counselors' attitude toward university counseling and counselors duties; Babol dental school.. Iranian Quarterly of Education Strategies. Vol. 5, No. 2, summer 2012 Pages: 83-88

Shafiabadi A. [Moshkelat daneshjoyan va zarorate taasis marakez moshavereh dar daneshgah]. Pajohesh dar Masael Talim va Tarbiat 1995 Spring; (4): 105. (In Persian)

Shams B, Farshidfar M, Hasanzadeh A. [Effect of consulting on the achievement of university students With dropout]. Iranian Joumal of Medical Education 2000; 1(1): 36-41. (In Persian)

Shams B, Garakyaraghi M, Ebrahimi A, Avizgan M, Gyahchin A. [The Problems of educational period and the proper reference for solving them: medical students' viewpoints in Isfahan University of Medical Sciences]. Iranian Joumal of Medical Education 2006; (6)2: 63-9. (In Persian)

The University of Texas. The faculty advisor's role. [2001 Agu 18]. Available from: hitp:// www.uta.edu

/advisorhandbook/faculty.advisor-htm

Van Luik SJ, Smeets JG, Wolfhagen I, PerquinM L. Assessing professional behaviour and the role ofacademic advice at the Maastricht Medical School. Med Teacher 2000 Mar; 22(2): 168-72. 